\title{
sciendo
}

Transport and Telecommunication, 2019, volume 20, no. 4, 346-356

Transport and Telecommunication Institute, Lomonosova 1, Riga, LV-1019, Latvia

DOI 10.2478/ttj-2019-0028

\section{MODELLING THE EFFECT OF INFORMATION AND COMMUNICATION TECHNOLOGY ON ACTIVITY-BASED TRAVELS, CASE STUDY: TEHRAN}

\author{
Ali Edrisi ${ }^{1}$, Peyman Ashkrof ${ }^{2}$, Houmaan Ganjipour ${ }^{3}$ \\ Department of Civil Engineering, K.N.Toosi University of Technology, No. 1346, Vali Asr Street, \\ Mirdamad Intersection, Tehran, Iran. P.O.Box: 15875-4416, Postal Code: 19697 \\ ledrisi@kntu.ac.ir \\ ${ }^{2}$ p.ashkrof@mail.kntu.ac.ir \\ 3 ganjipour.h@email.kntu.ac.ir
}

\begin{abstract}
Information and communication technology (ICT) has revolutionized almost all aspects of human life. Thus, examining the effect of this technology on social problems such as traffic congestion, environmental pollution, urban design, land use etc. is of immense importance for transportation planning. Using 303 questionnaires completed correctly by residents of Tehran, this study applied Structural Equation Modelling to investigate the effect of ICT usage in a broader definition on 27 types of out-of-home activities, which were classified into three categories of subsistence, maintenance and leisure activities. The results showed the complementary/generation effect of ICT usage on travel demand. The use of ICT was also found to increase the time spent on subsistence activities and decrease the time spent on maintenance activities, as out-of-home maintenance activities can be carried out more easily and rapidly by Internet, and so people naturally prefer to follow this approach.
\end{abstract}

Keywords: ICT, Activity-based travel, Structural Equation Modeling, Complementary, Maintenance activities, subsistence activities

\section{Introduction}

Information and Communication Technology (ICT) consists of all advanced communication and data transmission technologies that form the modern communication systems. These technologies have revolutionized many of the traditional human activities, making them easier, faster, and economic. Furthermore, this technology-driven revolution is manifested in concepts such as e-working, e-shopping and e-learning. After the advent of ICT, the use of ICT-based tools increased at a significant rate. ICT capabilities can simplify the activity-based travels in the urban transportation system, so the impact of these capabilities on different types of travel is particularly important for transportation planners. It is noteworthy that the use of ICT has increased in Tehran in the recent years. For instance, from 4,211,229 households in Tehran, 2,683,972 households have access to the internet, while 2,738,765 households and $4,175,236$ households use computers and cell phones respectively in 2016. It shows more than half of Tehran population is currently using different kinds of ICT (Statistical Centre of Iran, 2015).

Outdoor activities can be divided into three categories: a) Subsistence activities, which are related to the work, such as going to work, school or university. b) Maintenance activities, which are a series of actions performed to meet the households' physiological or biological needs such as buying food, taking children to/from school, visiting doctor, going to the bank. c) Leisure activities, which are the set of outdoor activities related to their leisure, which includes going to the cinema, visiting friends and relatives, and going to sports activities.

ICT usage can affect the aforementioned activities in four ways including: 1) Substitution: ICT usage may reduce the activity-based travels by providing alternative solutions to eliminate the demand. 2) Complementary/generation: ICT usage may generate new travels that would not be made in its absence. 3) Modification: ICT usage may transform the travels not by removing and replacing them but by altering different aspects of the travels including the travel time, travel chain and travel mode. 4) Neutrality: sometimes ICT usage may have no effect on individual activities and their related travels (Mokhtarian, 2004).

The purpose of this study is to investigate the effect of ICT usage (e-working, e-shopping, e-learning, etc.) on the travel behaviour and the number of daily travels more precisely for a longer term. It can determine that the allocated time of which activities (leisure, subsistence, maintenance) is whether 
affected by ICT positively or negatively, and to see whether ICT decreases or increases the total number of daily travels. As a result, it is possible to control the time and number of these activities during the peak hours to prevent the production of unnecessary travels regarding the development of ICT. Overall, most researches that have studied the short-term and small-scale effect of ICT usage on travel have found a substitution relationship, but those focusing on large-scale and long-term effects have reported that ICT usage contributes to generate more travels. The aim of the present study is to examine and combine the above-mentioned factors to develop a model for a long-term planning. According to literature, the relationship between ICT usage and travel can be examined via two approaches: a) aggregate level (general) studies, and b) disaggregate level. The following sections will shed light on these two approaches.

\subsection{The Aggregate Level}

As one of the earliest aggregate studies, Selvanathan E.A. and Selvanathan S. (1994) evaluated a simultaneous equation system of consumer demand for four types of service: private transport, public transport, communication tools, and other services. This study, which was based on data pertaining to the period of 1960-1986 from two countries, Australia and the United Kingdom, reported that private transport, public transport, and communication tools have a pairwise substitution relationship. It was also reported that any increase in the price of one service increases the demand for other services. Plaut (1997) described the relationship between transportation and communication services in the industrial sector of nine European countries, and stated that about two-thirds of all transportation and communication services are being used by the industrial sector. He also used input-output analysis to determine the complementary effect between transportation and communication units. Plaut (1999) has also showed this complementary effect for non-EU countries. Senbil and Kitamura (2003) used 766 samples taken from Osaka, Japan, to examine the relationship between the telecommunication tools (landline and cell phone) and subsistence and maintenance activities. After using the number of landline and mobile calls as exogenous variables of structural equation model, they found that telecommunication tools have a substitution relationship with work activities, a complementary/generation relationship with leisure activities, and a neutrality relationship with maintenance activities. Wang and Law (2007) examined the effects of ICT skills (experience of using email, Internet and video calls) on the time spent on the three types of activities as well as travel behaviour. They used structural equation model based on daily activities of 4,395 respondents in Hong Kong and found that the use of ICT increases the outdoor leisure activities, the total number of travels, and travel time. The results demonstrated the complementary relationship between the use of ICT and travel.

Choo et al. (2010) used travel generation models to examine the relationship between travel and ICT usage (landline and cell phone call time per day, and the time spent online per day). This study was based on data of 269 respondents in South Korea regarding their daily activities and the use of ICT. The relationship of variables was examined with regression and structural equation models and both models showed that the use of ICT increases the travel, which means they have a complementary relationship. Ren and Kwan (2009) used a structural equation model based on the information gathered on normal daily activities and the use of Internet in two midweek days, in order to examine the complex relationship between different types of physical and Internet activities, while focusing on the impact of travellers' gender on leisure and maintenance activities. This study proves that the effect of Internet activities on travel pattern varies based on the gender. Dal Fiore et al. (2014) outlined a vision of how smart phones and computers will affect the future travels. They stated that mobile technology can induce new behaviours in travellers, sometimes reducing and other times increasing the number of travels by changing the costs and benefits. Ben-Elia et al. (2014) studied the interaction between ICT, activity fragmentation and travel behaviour, and stated that the idea of activity fragmentation is associated with how to divide the activities into smaller components so that these components can be spatially and temporally reorganized with ICT.

Pawlak et al. (2015) presented a framework for joint modelling of ICT bundle, travel mode and the choice of physical or virtual activity. Lila and Anjaneyulu (2016) explored the impact of ICT on the activity and travel behaviour in Bangalore, India. The Structural Equation Modelling showed that ICT generated more leisure activities. Van Wee (2015) discussed about the increasing of ICT-based activity patterns and their replacement with travel among young people. In the same topic, Delbosc and Mokhtarian (2018) examined the relationship between physical and virtual social interaction. They concluded that social media use could not reduce travel demand among younger people. In addition, Vine et al., (2016) indicated that internet usage correlated positively with time spent at out-of-home activities 
and travelling. Finally, it should be noted that new theoretical and methodological advances are employed for discussing the interrelationship between ICT, activity, time use and mobility (Ben-Elia et al., 2018).

In this study, travel-activity-communication information pertaining to a two-day period was gathered, and was then used in a path analysis for modelling based on demographic and land use factors. The results showed that activity fragmentation decreases the work travels, limits the prospect of private non-work travels, and can allocate more time to travel and leisure activities.

\subsection{The Disaggregate Level}

Differing from the aggregate studies, most disaggregate empirical studies have focused on specific telecommunications applications, such as telecommuting, e-shopping and teleconferencing. The short-term impact of telecommuting on transport has been the subject of a number of empirical studies (Hamer et al., 1991; Pendyala et al., 1991; Koenig et al., 1996; Henderson and Mokhtarian, 1996; Mokhtarian and Varma, 1998). These studies reported that telecommuting decreased the roundtrip commute distance, but had no significant impact on one-way commute distance. They also reported that the effect of changes in transportation mode, either using public transport, carpooling or personal car, was insignificant. One of the popular applications of ICT is teleconferencing which means using the audio-visual tools to hold meeting with people from different locations. Teleconferencing can be significantly used for organizational and business meetings, either to create or share high-quality information by increasing the number of participants or/and to reduce the travel costs, and can act as a complementary means to physical travel. Teleconferences are easier to arrange, so they allow the meetings to be held more frequently and with more participants, however, occasionally there is a need to produce a physical trip to access the hardware required to attend the web conference. Teleconferences can also replace the routine business travels, allowing the time and money to be saved for more sensitive meetings (Mokhtarian, 1998). Another application of ICT is e-shopping. Mokhtarian and Salomon (2002) studied the impact of e-commerce and e-shopping on travel behaviour and reported that the time saved due to e-shopping may be assigned to other travels. The empirical studies based on structural equation modelling found that the time saved by women would be assigned to additional shopping and other maintenance activities (Gould and Golob, 1997; Gould et al., 1998). Mokhtarian (2004) suggested that ICT leads to fragmentation and recombination of basic elements of shopping process, and reported that many factors can affect the interaction between e-shopping, and while some results show that e-shopping reduces the travel, other results indicate the opposite. She concluded that the ultimate effect of eshopping on travel could be negative (generation of more travel). Recent studies focus on product type (search goods and experience goods) to explore the interaction between e-shopping and in-store shopping for them (Zhen et al., 2016; Zhai et al., 2017; Zhen et al., 2018). The research of Thulin and Vilhelmson (2007) suggested that they are activities that generate travel and the impact of ICT on travel must be defined based on transformation or facilitation of participation in activities and the time needed for these activities. They reported that using ICT allows the physical activities such as going to bank to be replaced with alternatives such as e-banking and while this replacement has a direct substitution effect, it may also have indirect travel generation or modification effects. The next sections introduce the model used in this study, describe the method of data collection, and finally present the structural equation model.

\section{Methodology}

\subsection{Data Collection}

Data collected for this study includes the extent of ICT usage, details of participation in physical activities (i.e. trips made) during two midweek days (the reasons for engaging in the activity, activity time, travel time associated with the activity, travel mode, etc.) and socio-demographic variables. The participants consisted of Tehran residents and were not limited to any particular age group, social class or education level. Depending on respondents' physical or psychological conditions, some may fail to fill the questionnaire in full, or may provide vague or irrational responses. So, a total of 355 questionnaires were collected through random personal interview in universities, shopping centres, the book fair, festivals, and other busy places with considering different age group, gender, education level, income level, job category, diversity of attitudes, etc. during the spring of 2015. In order to increase the accuracy of the analysis those questionnaires with missing data in some parts were neglected and dropped from the pool of analysed questionnaires. Consequently, in total 303 questionnaires were selected for initial analysis. (Response rate $=86 \%$ ).

The questionnaire consisted of three different sections: (i) ICT usage of respondents; (ii) out-ofhome activities of individuals during two midweek days; (iii) socio-economic questions such as gender, age, education, etc. The questionnaire was filled out in midweek days at evening because the second part questioned the out-of-home activity in that exact day and the day before since travel behaviour might 
change during the weekend in terms of trip purpose and consequently the time spent for each travel. Thus, this paper has focused on travel behaviour during the working days since the travel routine could be examined better during the working days while covering the major part of the week. Overall, data collection phase took about forty days to be completed. Descriptive analysis of data was performed with the SPSS. 23 software. Some of the results of this analysis are listed in Table 1. According to these results, the age range with the highest frequency of respondents was 21-25 years old, and the ones with the lowest frequency were 56-60 years old, and above 60 years old.

Table 1. Demographic characteristics of respondents

\begin{tabular}{|c|c|c|}
\hline Variables & Frequency/Mean & Percentage \\
\hline Male & 117 & 38.6 \\
\hline Female & 186 & 61.4 \\
\hline Single & 185 & 61.1 \\
\hline Married & 118 & 38.9 \\
\hline Employed & 179 & 59.1 \\
\hline Unemployed & 124 & 40.9 \\
\hline Below a bachelor degree & 95 & 31.3 \\
\hline Bachelor degree & 125 & 41.3 \\
\hline Higher than a bachelor degree & 83 & 27.4 \\
\hline Experience of using e-mail (use at least once a week) & $241(158)$ & $79.5(52)$ \\
\hline Experience of using e-working (use at least once a week) & $191(139)$ & $63(46)$ \\
\hline Experience of using e-shopping services (use at least once a week) & $218(112)$ & $71.9(37)$ \\
\hline Experience of using e-banking services (use at least once a week) & $209(106)$ & $69(35)$ \\
\hline Experience of using e-learning services (use at least once a week) & $135(72)$ & $44.6(24)$ \\
\hline Experience of using video calls & 149 & 49.2 \\
\hline Experience of using web-based video & 218 & 71.9 \\
\hline Experience of using cell phone more than 1 hour per day & 161 & 53 \\
\hline spend less than 1 hour a day online & 185 & 61 \\
\hline $\begin{array}{l}\text { Time used for Subsistence activities per day (minute) } \\
{[\mathrm{Min}=0.0, \mathrm{Max}=1020, \text { Standard deviation=3.27] }}\end{array}$ & 331.8 & - \\
\hline $\begin{array}{l}\text { Time used for Maintenance activities per day (minute) } \\
{[\text { Min }=0.0, \operatorname{Max}=615, \text { Standard deviation }=1.49]}\end{array}$ & 60 & - \\
\hline $\begin{array}{l}\text { Time used for Leisure activities per day (minute) } \\
{[\text { Min }=0.0, \text { Max }=240, \text { Standard deviation }=0.69]}\end{array}$ & 20 & - \\
\hline $\begin{array}{l}\text { Total number of daily trips } \\
{[\text { Min }=0.0, \text { Max }=5, \text { Standard deviation }=0.78]}\end{array}$ & 2.56 & - \\
\hline Age & 30.21 & - \\
\hline
\end{tabular}

\subsection{Research Model}

In this study, Structural Equation Modelling (SEM) was employed for estimating the relationship between observed variables (that can be directly measured) and latent variables (that cannot be directly or exactly measured). SEM has two components: measurement model (specifies that how latent variable is associated with its observed variables) and structural model (determines the relationships among latent variables or the relationships between latent variables and observed variables that are not indicators of latent variables). The structural model estimates the effects of exogenous variables (independent) on endogenous variables (dependent) or the effects of endogenous variables on each other. In addition, this model can estimate the coefficients of direct effect, indirect effect and total effect of variables on each other. SEM can be represented as:

$\mathrm{Y}=\mathrm{BY}+\Gamma \mathrm{X}+\zeta$,

where $\mathrm{Y}$ is a $\mathrm{k} \times 1$ matrix containing the endogenous variables ( $\mathrm{k}$ : the number of endogenous variables). $\mathrm{X}$ is a $\mathrm{j} \times 1$ matrix containing the exogenous variable ( $\mathrm{j}$ : the number of exogenous variables). $\mathrm{B}$ is a $\mathrm{k} \times \mathrm{k}$ matrix representing the relationships among endogenous variables. $\Gamma$ is a $\mathrm{k} \times \mathrm{j}$ matrix representing the effects of exogenous variables on endogenous variables and $\zeta$ is a $\mathrm{k} \times 1$ matrix representing the error.

\section{Results}

\subsection{Measurement model}

The model is founded on the theory developed by Golob (2000). According to Golob theory, travel is derived from activity participation and also the ICT-induced changes in time allocation for activities may lead to changes in travel behaviour. He has provided the activity-based conceptual model shown in Figure 1. Following Golob's theory, in this study, travel is defined as the out-of-home activity. 


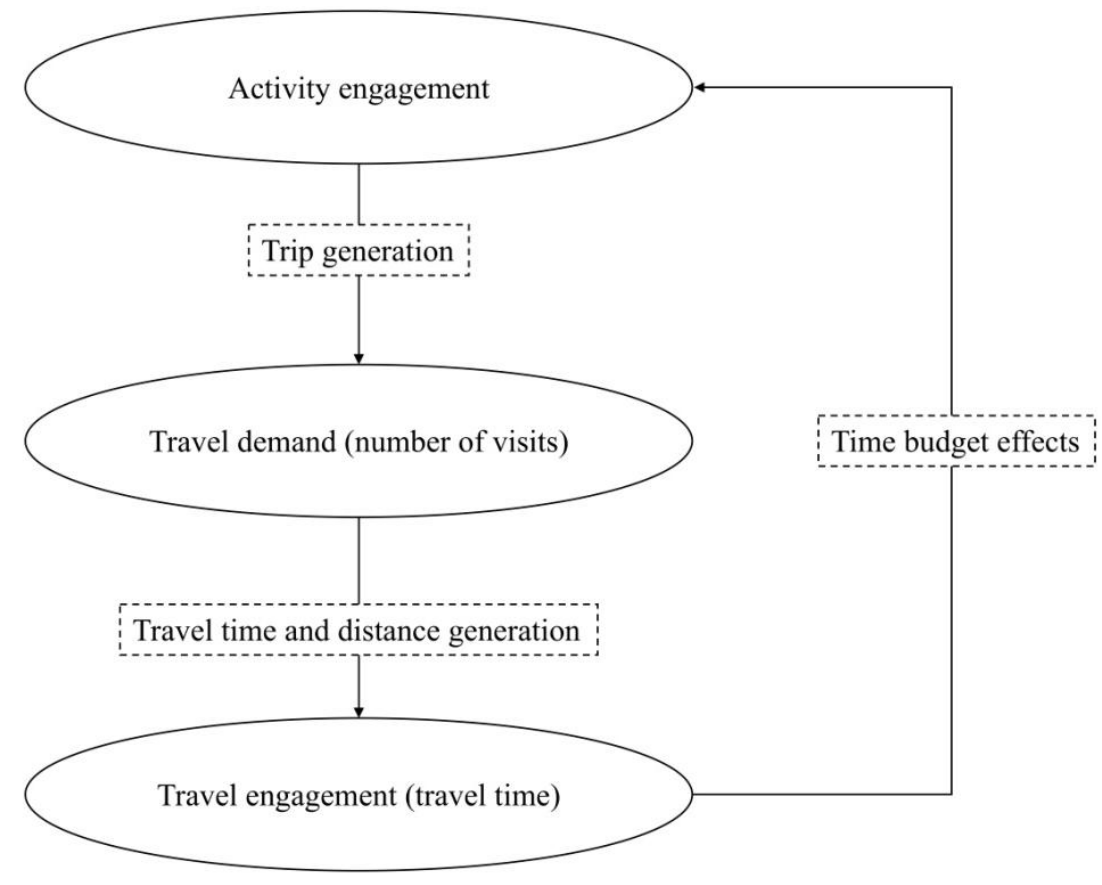

Figure 1. Relationship between activity and travel (Golob, 2000)

In this study, the rate of ICT usage was considered as a latent variable because it might not be measured directly. It can be measured by nine observed variables (questionnaire items): cell phone usage per day, Internet usage per day, frequency of checking e-mail, frequency of e-shopping, e-banking, telecommuting, video calls, usage of e-learning services, and watching online videos. In measurement model, the factor loading for every item was investigated based on Maximum Likelihood Estimation (MLE). According to the one latent variable, nine observed variables and factor loading (which is 0.5 ); the minimum required data for modelling is 90 questionnaires (Wolf et al., 2013). However, in order to have a more precise analysis, in this study 303 questionnaires are analysed. The results of standardized and nonstandardized coefficients, error, T statistic, and P statistic are shown in Table 2. It should be noted that in measurement models, one of the observed variables value is fixed to one called fixed parameter, in order to make the calculation easier and then compare the coefficients with each other. Checking Email is a fixed parameter, therefore, the other values (SE, T-value, and P-value) are not calculated.

Table 2. Standardized coefficients of measurement model

\begin{tabular}{|c|c|c|c|c|c|}
\hline Variables & & Estimate & S.E & T-value & P-value \\
\hline $\mathrm{ICT} \longrightarrow$ & Checking mail & $0.717^{\mathrm{a}}$ & - & - & - \\
\hline $\mathrm{ICT} \longrightarrow$ & Mobile usage & 0.073 & 0.084 & 1.1 & 0.271 \\
\hline $\mathrm{ICT} \longrightarrow$ & Internet usage & 0.341 & 0.075 & 5.010 & $0.001 *$ \\
\hline ICT $\longrightarrow$ & E-shopping & 0.605 & 0.087 & 8.268 & $0.001 *$ \\
\hline ICT & E-banking & 0.597 & 0.089 & 8.193 & $0.001 *$ \\
\hline ICT & E-working & 0.543 & 0.112 & 7.608 & $0.001 *$ \\
\hline $\mathrm{ICT} \longrightarrow$ & Video call & 0.398 & 0.094 & 5.791 & $0.001 *$ \\
\hline $\mathrm{ICT} \longrightarrow$ & E-learning & 0.361 & 0.084 & 5.294 & $0.001 *$ \\
\hline $\mathrm{ICT} \longrightarrow$ & Watching online & 0.195 & 0.103 & 2.927 & 0.003 \\
\hline
\end{tabular}

a Item fixed on 1.00

*: p-value $<0.001$

Goodness of fit indices: $\chi^{2}=58.046$, Degrees of freedom $(\mathrm{df})=27, \chi^{2} / \mathrm{df}=2.15$ (should be less than 3), Root Mean Square Error of Approximation (RMSEA) = 0.062 (should be less than 0.08), Comparative Fit Index $(\mathrm{CFI})=0.907$ (should be greater than 0.9 ) 


\subsection{Structural model}

After applying Confirmatory factor analysis (CFA) in the first step of modelling, the structural model was developed using AMOS23 software. For this purpose, time spent on out-of-home subsistence, maintenance and leisure activities, the total number of daily trips and ICT usage were considered as endogenous variables, and socio-demographic variables including gender, age, education level, employment status and occupation were used as exogenous variables. The hypothesized relationship between endogenous and exogenous variables is shown in Figure 2.

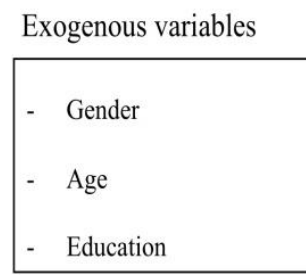

Endogenous variables

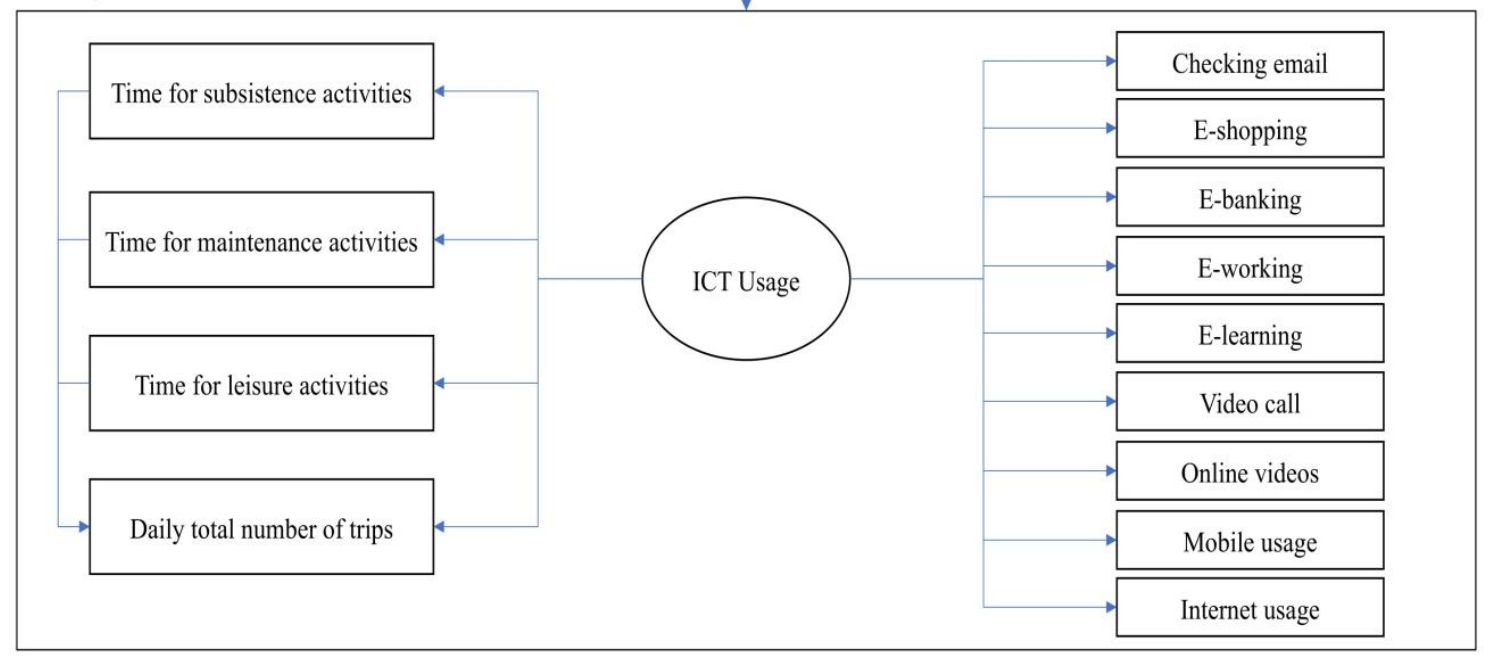

Figure 2. Hypothetical causal links between ICT usage, time use, travel behaviour and socio-demographics

Table 3 and 4 show the relationships among endogenous variables and the relationships between endogenous variables and exogenous variables, respectively. The hypothetical causal links between variables have been derived by the measurement model and literature review. In addition, literature review and past experience show that there are some internal relationships between endogenous and exogenous variables. The hypothetical links used in this model have inspired one the most suitable one described in Wang and Law (2007). In fact, ICT usage has been measured by one question (do you use the internet?) in Wang's model while in this study, it is considered as a latent variable and can be measured by nine observed variables.

Table 3. Standardized coefficients of structural model (Relation between endogenous variables)

\begin{tabular}{|l|c|c|c|c|}
\hline Relation between endogenous variables & Estimate & S.E & T-value & P-value \\
\hline $\mathrm{ICT} \longrightarrow$ Subsistence & 0.328 & 0.171 & 4.994 & $0.001^{*}$ \\
\hline $\mathrm{ICT} \longrightarrow$ Maintenance & -0.121 & 0.075 & -1.917 & 0.055 \\
\hline $\mathrm{ICT} \longrightarrow$ Leisure & -0.105 & 0.038 & -1.518 & 0.129 \\
\hline $\mathrm{ICT} \longrightarrow$ & 0.200 & 0.041 & 3.042 & 0.002 \\
\hline Subsistence $\longrightarrow$ Total number of daily trips & -0.394 & 0.025 & -7.106 & $0.001^{*}$ \\
\hline Subsistence $\longrightarrow$ Maintenance & -0.207 & 0.014 & -3.194 & 0.001 \\
\hline Subsistence $\longrightarrow$ Leisure & 0.305 & 0.014 & 5.299 & $0.001^{*}$ \\
\hline Maintenance $\longrightarrow$ Total number of daily trips & -0.166 & 0.029 & -2.650 & 0.008 \\
\hline Subsistence $\longrightarrow$ Leisure & -0.538 & 0.029 & 9.700 & $0.001^{*}$ \\
\hline Leisure $\longrightarrow$ Total number of daily trips & 0.292 & 0.057 & 5.806 & $0.001^{*}$ \\
\hline
\end{tabular}

$*$ : p-value $<0.001$ 
Table 4. Standardized coefficients of structural model (Relation between endogenous and exogenous variables)

\begin{tabular}{|l|c|c|c|c|c|}
\hline Relation between endogenous and exogenous variables & Estimate & S.E & T-value & P-value \\
\hline Gender $\longrightarrow$ ICT & 0.309 & 0.149 & 5.330 & $0.001^{*}$ \\
\hline Age $\longrightarrow$ ICT & -0.233 & 0.007 & -4.100 & $0.001^{*}$ \\
\hline Education $\longrightarrow$ ICT & 0.334 & 0.052 & 5.710 & $0.001^{*}$ \\
\hline Work Status $\longrightarrow$ ICT & 0.323 & 0.148 & 5.554 & $0.001^{*}$ \\
\hline Occupation $\longrightarrow$ ICT & -0.154 & 0.023 & -2.741 & 0.006 \\
\hline Education $\longrightarrow$ Total number of daily trip & -0.095 & 0.029 & -1.800 & 0.072 \\
\hline
\end{tabular}

$*$ : p-value $<0.001$

The next subsections describe first the effect of ICT usage on the time spent on activities and travel behaviour and then the effect of demographic variables on ICT usage, activities and travel behaviour.

\section{Discussion}

\subsection{The effect of ICT usage on the time spent on activities and travel behaviour}

Table 5 shows the direct, indirect and total effect (sum of direct and indirect effects) of endogenous variables on each other (relationship between the times of activities and travel behaviour irrespective of the effect of ICT usage on these parameters). According to this table, direct and total effect of ICT usage on subsistence activities are both positive, which means that ICT usage lead to allocation of more time to subsistence activities. (This result is consistent with Wang and Law (2007)). Whereas, direct, indirect and total effects of ICT usage on maintenance activities are all negative, which indicate that ICT usage reduces the time allocated to maintenance activities both directly and indirectly. Considering the prevalent usage of internet, nowadays, out-of-home maintenance activities are conducted easier and quicker which have persuaded many people to use it. It should be noted that although ICT usage showed a negative impact on leisure activities, the significance level of this impact was less than $90 \%$, so it was disregarded. However, this insignificance may be due to the selection of two midweek days for the study which may be considered unsuitable for leisure activities. Overall, it can be concluded that ICT usage reduces the time spent on maintenance activities by eliminating activities such as going to the bank or shopping, and part of this saved time is spent on subsistence activities. This might be because of the stagnant economic conditions at the time of the study and people might work overtime. The table also shows the positive signed direct and total effects of ICT usage on the total number of daily travels; however, the indirect effect of ICT usage on this parameter is negative, although it could be neglected due to the low value it presents, i.e. -0.073. Nevertheless, according to Table 6, which shows the role of intermediary factors in indirect relationship of ICT usage with activity-based travel behaviour, much of the above-mentioned negative effect is due to maintenance activities.

Table 5. Standardized total, direct and indirect effects between endogenous variables

\begin{tabular}{|l|c|c|c|c|c|c|}
\hline \multicolumn{1}{|c|}{ Variables } & Type of effect & Use of ICT & $\begin{array}{c}\text { Subsistence } \\
\text { activity }\end{array}$ & $\begin{array}{c}\text { Maintenance } \\
\text { activity }\end{array}$ & $\begin{array}{c}\text { Leisure } \\
\text { activity }\end{array}$ & $\begin{array}{c}\text { Number of } \\
\text { trips }\end{array}$ \\
\hline \multirow{3}{*}{ Use of ICT } & Total & 0 & 0.328 & -0.250 & -0.131 & 0.127 \\
& Direct & 0 & 0.328 & -0.121 & -0.105 & 0.200 \\
\hline \multirow{2}{*}{ Indirect } & 0 & 0 & -0.129 & -0.026 & -0.073 \\
activity & Total & 0 & 0 & -0.394 & -0.141 & 0.051 \\
& Direct & 0 & 0 & -0.394 & -0.207 & 0.305 \\
Maintenance & Indirect & 0 & 0 & 0 & 0.066 & -0.254 \\
activity & Total & 0 & 0 & 0 & -0.166 & 0.166 \\
\hline \multirow{2}{*}{ Leisure } & Indirect & 0 & 0 & 0 & 0.539 \\
activity & Total & 0 & 0 & 0 & 0 & -0.049 \\
\hline
\end{tabular}

Goodness of fit indices: $\chi^{2}=367.685$, Degrees of freedom $(\mathrm{df})=128, \chi^{2} / \mathrm{df}=2.873$ (should be less than 3), Root Mean Square Error of Approximation (RMSEA) = 0.079 (should be less than 0.08), Goodness of Fit Index $(\mathrm{GFI})=0.881$ and Adjusted Goodness of Fit Index (AGFI) $=0.841$ (should be greater than 0.9) 
Table 6. The indirect effect of ICT usage on activity-based travel behaviour

\begin{tabular}{|l|c|}
\hline Variables & Indirect effect \\
\hline Time used for Subsistence activities & +0.1 \\
\hline Time used for Maintenance activities & -0.135 \\
\hline Time used for Leisure activities & -0.038 \\
\hline Total & -0.073 \\
\hline
\end{tabular}

According to table 5, the time spent on subsistence activities has an inverse relationship with the time spent on maintenance and leisure activities. Moreover, the number of travels has increased with the increase of this time. Alike subsistence activities, the time spent on maintenance activities has an inverse relationship with the time spent on leisure activities, and a positive relationship with the total number of daily travels. These results are obviously expectable, because the more time we dedicate to a particular activity, the less time we have for other activities, and the more time we dedicate to out-of-home activities the more travel we generate.

Some Studies have reported that the use of ICT tools, especially the Internet, leads to generation of more travel (Srinivasan and Reddy Athuru, 2004; Wang and Law, 2007). One of its reasons is that the time saved by reducing the out-of-home maintenance activities is mostly used to do more subsistence activities, which according to the Golob theory, leads to increased number of travels. So the results support the complementary/generation effect of ICT usage on the number of travels reported in some of the previous studies (Salomon, 1986; Mokhtarian, 2002; Wang and Law, 2007; Choo et al., 2010; Ren and Kwan, 2009).

\subsection{The effect of exogenous variables on endogenous variables}

As Table 7 shows, most socio-demographic variables affect the ICT usage. Age was found to have a significant negative impact on the ICT usage. This result supports the reports of previous studies stating that younger people are more willing to use ICT tool (Casas et al., 2001). This could be because young people are more knowledgeable about the ICT concepts and more willing to explore new technologies, including ICT applications such as the Internet, mobile, video call and others. The results obtained about gender show that men are more willing to use ICT tools. The reason behind this observation could be that women are more inclined to certain physical activities such as traditional shopping, which means they are less inclined to replace them with ICT applications such as e-shopping. It also shows that employment status has a positive relationship with the ICT usage, which means employed people use ICT tools more frequently. This could be because employed people often try to do all their activities as quickly as possible and also have better access to the financial resources required for the use of ICT tools.

Table 7. Standardized total, direct and indirect effects between endogenous and exogenous variables

\begin{tabular}{|c|c|c|c|c|c|c|}
\hline Variables & Type of effect & Use of ICT & $\begin{array}{c}\text { Subsistence } \\
\text { activity }\end{array}$ & $\begin{array}{c}\text { Maintenance } \\
\text { activity }\end{array}$ & $\begin{array}{l}\text { Leisure } \\
\text { activity }\end{array}$ & $\begin{array}{c}\text { Number of } \\
\text { trips }\end{array}$ \\
\hline Gender & $\begin{array}{c}\text { Total } \\
\text { Direct } \\
\text { Indirect }\end{array}$ & $\begin{array}{c}0.309 \\
0.309 \\
0\end{array}$ & $\begin{array}{c}-0.101 \\
0 \\
-0.101\end{array}$ & $\begin{array}{c}-0.077 \\
0 \\
-0.077\end{array}$ & $\begin{array}{c}-0.04 \\
0 \\
-0.04\end{array}$ & $\begin{array}{c}0.039 \\
0 \\
0.039\end{array}$ \\
\hline Age & $\begin{array}{c}\text { Total } \\
\text { Direct } \\
\text { Indirect }\end{array}$ & $\begin{array}{c}-0.233 \\
-0.233 \\
0 \\
\end{array}$ & $\begin{array}{c}-0.077 \\
0 \\
-0.077 \\
\end{array}$ & $\begin{array}{c}0.058 \\
0 \\
0.058 \\
\end{array}$ & $\begin{array}{c}0.031 \\
0 \\
0.031 \\
\end{array}$ & $\begin{array}{c}-0.03 \\
0 \\
-0.03 \\
\end{array}$ \\
\hline Education & $\begin{array}{c}\text { Total } \\
\text { Direct } \\
\text { Indirect }\end{array}$ & $\begin{array}{c}0.334 \\
0.334 \\
0 \\
\end{array}$ & $\begin{array}{c}0.11 \\
0 \\
0.11 \\
\end{array}$ & $\begin{array}{c}-0.084 \\
0 \\
-0.084 \\
\end{array}$ & $\begin{array}{c}-0.044 \\
0 \\
-0.044 \\
\end{array}$ & $\begin{array}{c}-0.053 \\
-0.095 \\
0.043 \\
\end{array}$ \\
\hline Work Status & $\begin{array}{c}\text { Total } \\
\text { Direct } \\
\text { Indirect }\end{array}$ & $\begin{array}{c}0.323 \\
0.323 \\
0 \\
\end{array}$ & $\begin{array}{c}0.106 \\
0 \\
0.106 \\
\end{array}$ & $\begin{array}{c}-0.081 \\
0 \\
-0.081 \\
\end{array}$ & $\begin{array}{c}-0.042 \\
0 \\
-0.042 \\
\end{array}$ & $\begin{array}{c}0.041 \\
0 \\
0.041 \\
\end{array}$ \\
\hline
\end{tabular}

Goodness of fit indicators: $\chi^{2}=367.685$, Degrees of freedom $(\mathrm{df})=128, \chi^{2} / \mathrm{df}=2.873$ (should be less than 3), Root Mean Square Error of Approximation (RMSEA) $=0.079$ (should be less than 0.08), Goodness of Fit Index $(\mathrm{GFI})=0.881$ and Adjusted Goodness of Fit Index $(\mathrm{AGFI})=0.84$ (should be greater than 0.9 ).

This table also shows that level of education has a positive impact on the ICT usage meaning that more educated people are more inclined to use ICT tools. This is because educated people are generally more familiar with new technologies and more willing to adapt their lifestyle to new concepts.

Socio-demographic variables showed some effects on the time spent on subsistence, maintenance, and leisure activities as well as travel behaviour. The positive coefficient of gender effect on subsistence 
activities and the number of travels and the negative coefficient of its effect on maintenance and leisure activities indicate that men have a higher number of subsistence activities and daily travels while women have a higher number of maintenance and leisure activities. This might be due to the socio-cultural context where men are perceived as the main breadwinner of the families, thus they are more likely to engage in subsistence activities. Examining the age coefficients shows that older people have less subsistence and travel frequency and more maintenance and leisure activities. This might be because older people have lower subsistence or maintenance concerns and are more likely to rest or engage in leisure activities. The results show that people with higher education have a lower travel frequency, but they have negative maintenance and leisure coefficients and positive subsistence coefficient. In other words, more educated people tend to spend more time on subsistence activities and less time on maintenance and leisure ones. Employed people were found to have a lower frequency of maintenance and leisure activities, higher frequency of subsistence activities, and higher number of travels.

\section{Conclusions}

Today, development of modern science has entwined our life with the concepts of Information and Communication Technology (ICT) to the extent that some of our daily activities seem impossible without it. Thus, examining the effect of this technology on social problems such as traffic congestion, environmental pollution, urban design, land use etc. is significantly important for transportation planning. A deep understanding about the impact of ICT usage on individual or organized travels can also be beneficial in the fields such as information systems, economics and commerce. In developing countries such as Iran, the use of ICT is increasing at a rapid rate, so careful examination of ICT impacts on activity-based travel behaviour of the users of transportation system can contribute to improvement of transportation planning to tackle the traffic problems as the dilemma in metropolises.

This study examined the complex relationship among the ICT usage, and engagement in activities, travel behaviour and demographic variables. In the sampling process conducted in the city of Tehran during the spring of 2015, a total of 355 samples were collected, of which 303 were entered into the model. A structural equation model was developed based on maximum likelihood estimation to determine the relationship between different research parameters using AMOS23 software. The results showed the complementary/generation effect of ICT usage on travel behaviour. In other words, ICT usage increases the number of daily travels. Furthermore, the ICT usage was found to increase the time allocated to subsistence activities and decrease the time spent on maintenance activities since out-of-home maintenance activities can be carried out more easily and rapidly by the Internet, and naturally, people prefer to use this method. It is notable that although ICT usage showed a negative effect on leisure activities, this effect was not statistically significance (\%86) Therefore, it can be stated that ICT usage has no direct effect on leisure activities. It was found that in case of a decrease in the time spent on out-ofhome maintenance activities, the saved time could indirectly lead to generation of new subsistence activities which leads to increased number of travels according to the Golob theory (Golob, 2000).

Considering that Iran is still a developing country and lacks the sufficient ICT infrastructure, policymakers may be able to control the demand for physical travels over medium and long terms through targeted development of ICT in e-banking, e-shopping, and e-working while teaching people how to use these capabilities correctly. In fact, people's awareness can be raised by public advertisement in the media so that they are taught how to use new technology efficiently in order to prevent to make a physical travel for the same purpose. Incorrect use of ICT might increase the total number of trips; however, the efficient ICT usage can significantly reduce travels. For example, ones might select a product via the internet but they may generate some trips for testing, evaluation or even purchasing it. So, it is possible to control these kinds of generated trips through educating people in terms of using the internet and trusting eshopping in order to avoid further trips. Furthermore, online shops can also encourage people toward eshopping by offering special services (reducing price, seasonal offers, increasing warranty or product return, and so on.) to avoid extra travels. As another example, banks can encourage their customers to use the Internet by offering some facilities and services or by restricting some banking activities to the internet bank.

It has been assumed that ICT usage as a latent variable influences travel behaviour and also all types of activities affect each other. This study has its own constraints like other questionnaire-based studies. Although the questions were designed in a simple way, most of them were filled out physically and it was needed to explain each part of questionnaire separately in order to ensure respondents understood the questions, so a lot of time spent in the clarification. An additional limitation of the data collected is possible sample bias. It is possible that individuals with strong pre-existing attitudes and preformed opinions towards ICT are more likely to respond to a survey about the topic. Though this is not a 
truly random sample, valid insight is provided through the disaggregate model controlling for individual characteristic. In addition, travel behaviour was surveyed just for two mid-day week in order to achieve the pattern (Revealed Preference); however, travellers usually go to work or school (substantial activity) during the week. Further research could investigate travel pattern for a longer period including weekends in order to gain a better understanding of RP.

Finally, we provide the following recommendations for future studies: a) this study considered only the user demand, but a more detailed analysis is needed to examine both supply and demand simultaneously. For example, the supply of transportation (expressed with the route-length available in the city and travel costs) and the supply of ICT infrastructure (expressed with the total length of provided wire and available Internet bandwidth) can be incorporated into the model. b) Like physical activities, virtual (online) activities can be categorized into three classes meaning that activities can be divided into the following categories: Physical activities (subsistence, maintenance, and leisure) and virtual activities (subsistence, maintenance, and leisure). c) Due to the physiological differences in the needs of men and women, they are naturally different in their physical and virtual activities. Therefore, further studies can be carried out with gender-specific settings. d) Transportation can have substitution or complementary effects on the use of ICT tools. For example, being trapped in a jammed highway can encourage the drivers to use cell phones and the Internet to acquire real-time traffic information and online routing guidance. So, the effect of transportation on the use of ICT tools can also be subjected to investigation.

\section{References}

1. Ben-Elia, E., Alexander, B., Hubers, C., Ettema, D. (2014) Activity fragmentation, ICT and travel: An exploratory Path Analysis of spatiotemporal interrelationships. Transportation Research Part A: Policy and Practice, 68, 56-74. DOI:10.1016/j.tra.2014.03.016.

2. Ben-Elia, E., Lyons, G., Mokhtarian, P.L. (2018) Epilogue: the new frontiers of behavioural research on the interrelationships between ICT, activities, time use and mobility. Transportation, 45(2), 479-497. DOI:10.1007/s11116-018-9871-x.

3. Casas, J., Zmud, J., Bricka, S. (2001) Impact of shopping via Internet on travel for shopping purposes. In 80th Annual Meeting of the Transportation Research Board, January 2001, Washington, DC.

4. Choo, S., Kim, I., Lee H. (2010) Exploring Relationships between Information and Communications Technology (ICT) Use and Travel. Journal of the Eastern Asia Society for Transportation Studies, 8 , 482-496. DOI:10.11175/easts.8.482.

5. Dal Fiore, F., Mokhtarian, P.L., Salomon, I., Singer, M.E. (2014) Nomads at last? A set of perspectives on how mobile technology may affect travel. Journal of Transport Geography, 41, 97-106. DOI:10.1016/j.jtrangeo.2014.08.014

6. Delbosc, A., Mokhtarian, P. (2018) Face to Facebook: The relationship between social media and social travel. Transport Policy, 68, 20-27. DOI:10.1016/j.tranpol.2018.04.005.

7. Golob, T.F. (2000) A Simultaneous Model of Household Activity Participation and Trip Chain Generation. Transportation research Part B, 34(5), 355-376. DOI:10.1016/S0191-2615(99)00028-4.

8. Gould, J., Golob, T.F. (1997) Shopping without travel or travel without shopping? An investigation of electronic home shopping. Transport Reviews, 17(4), 355-376. DOI:10.1080/01441649708716991.

9. Gould, J., Golob, T.F., Barwise, P. (1998) Why do people drive to shop? Future travel and telecommunications tradeoffs. Presented at the Annual Meeting of the Transportation Research Board, January 1998, Washington.

10. Hamer, R., Kroes, E., Van Ooststroom, H. (1991) Teleworking in the Netherlands: an evaluation of changes in travel behaviour. Transportation, 18(4), 365-382. DOI:10.1007/BF00186565.

11. Henderson, D.K., and Mokhtarian, P.L. (1996) Impacts of center-based telecommuting on travel and emissions: analysis of the Puget Sound Demonstration Project. Transportation Research Part D: Transport and Environment, 1(1), 29-45. DOI:10.1016/S1361-9209(96)00009-0.

12. Koenig, B.E., Henderson, D.K., Mokhtarian, P.L. (1996) The travel and emissions impacts of telecommuting for the State of California Telecommuting Pilot Project. Transportation Research Part C: Emerging Technologies, 4(1), 13-32. DOI:10.1016/0968-090x(95)00020-j.

13. Le Vine, S., Latinopoulos, C., Polak, J. (2016) Analysis of the relationship between internet usage and allocation of time for personal travel and out of home activities: Case study of Scotland in 2005/6. Travel Behaviour and Society, 4, 49-59. DOI:10.1016/j.tbs.2016.01.003

14. Lila, P.C., Anjaneyulu, M.V.L.R. (2016) Modeling the impact of ICT on the activity and travel behaviour of urban dwellers in Indian context. Transportation Research Procedia, 17, 418-427. DOI:10.1016/j.trpro.2016.11.083.

15. Mokhtarian, P.L. (1998) A synthetic approach to estimating the impacts of telecommuting on travel. Urban studies, 35(2), 215-241. DOI:10.1080/0042098984952. 
16. Mokhtarian, P.L. (2002) Telecommunications and travel: the case for complementarity. Journal of Industrial Ecology, 6(2), 43-57. DOI:10.1162/108819802763471771.

17. Mokhtarian, P.L. (2004) A conceptual analysis of the transportation impacts of B2C e-commerce. Transportation, 31(3), 257-284. DOI:10.1023/B:PORT.0000025428.64128.d3.

18. Mokhtarian, P.L., and Salomon, I. (2002) Emerging travel patterns: Do telecommunication make a difference? Perpetual Motion: Travel Behaviour Research Opportunities and Application Challenges. Pergamon, M. H. London.

19. Mokhtarian, P.L., and Varma, K.V. (1998) The trade-off between trips and distance travelled in analyzing the emissions impacts of center-based telecommuting. Transportation research part D: Transport and Environment, 3(6), 419-428. DOI:10.1016/S1361-9209(98)00018-2.

20. Pawlak, J., Polak, J.W., Sivakumar, A. (2015) Towards a microeconomic framework for modelling the joint choice of activity-travel behaviour and ICT use. Transportation Research Part A: Policy and Practice, 76, 92-112. DOI:10.1016/j.tra.2014.10.013.

21. Pendyala, R.M., Goulias, K.G., Kitamura, R. (1991) Impact of telecommuting on spatial and temporal patterns of household travel. Transportation, 18(4), 383-409. DOI:10.1007/BF00186566

22. Plaut, P. (1999) Do telecommunications reduce industrial uses of transportation? An international comparative analysis among Israel, North America and Europe. World Transport Policy and Practice, 5(4), 42-49.

23. Plaut, P.O. (1997) Transportation-communications relationships in industry. Transportation Research Part A: Policy and Practice, 31(6), 419-429. DOI:10.1016/S0965-8564(96)00036-5.

24. Ren, F., and Kwan, M.P. (2009) The impact of the Internet on human activity-travel patterns: analysis of gender differences using multi-group structural equation models. Journal of Transport Geography, 17(6), 440-450. DOI:10.1016/j.jtrangeo.2008.11.003.

25. Salomon, I. (1986) Telecommunications and travel relations: A review. Transportation research Part A, 20(3), 223-238. DOI:10.1016/0191-2607(86)90096-8.

26. Selvanathan, E.A., and Selvanathan, S. (1994) The demand for transport and communication in the United Kingdom and Australia. Transportation Research Part B: Methodological, 28(1), 1-9. DOI:10.1016/0191-2615(94)90027-2.

27. Senbil, M. and Kitamura, R. (2003) Simultaneous Relationships Between Telecommunications and Activities. In: 10th International Conference on Travel Behaviour Research, Lucerne, August 2003, pp. 10-15.

28. Srinivasan, K., Reddy Athuru, S. (2004) Modelling interaction between internet communication and travel activities: Evidence from Bay Area, California, Travel Survey 2000. Transportation Research Record: Journal of the Transportation Research Board, 1894, 230-240. DOI:10.3141/1894-24.

29. Statistical Center of Iran, 2015, https://www.amar.org.ir

30. Thulin, E., Vilhelmson, B. (2007) Mobiles everywhere Youth, the mobile phone, and changes in everyday practice. Young, 15(3), 235-253. DOI:10.1177/110330880701500302.

31. Van Wee, B. (2015) Peak car: The first signs of a shift towards ICT-based activities replacing travel? A discussion paper. Transport Policy, 42, 1-3. DOI:10.1016/j.tranpol.2015.04.002.

32. Wang, D., and Law, F.Y.T. (2007) Impacts of Information and Communication Technologies (ICT) on time use and travel behaviour: a structural equations analysis. Transportation, 34(4), 513-527. DOI:10.1007/s11116-007-9113-0.

33. Wolf, E.J., Harrington, K.M., Clark, S.L., Miller, M.W. (2013) Sample size requirements for structural equation models an evaluation of power, bias, and solution propriety. Educational and Psychological Measurement, 73(6), 913-934. DOI:10.1177/0013164413495237.

34. Zhai, Q., Cao, X., Mokhtarian, P.L., Zhen, F. (2017) The interactions between e-shopping and store shopping in the shopping process for search goods and experience goods. Transportation, 44(5), 885904. DOI:10.1007/s11116-016-9683-9.

35. Zhen, F., Cao, X., Mokhtarian, P.L., Xi, G. (2016) Associations between online purchasing and store purchasing for four types of products in Nanjing, China. Transportation Research Record: Journal of the Transportation Research Board, 2566, 93-101. DOI:10.3141/2566-10.

36. Zhen, F., Du, X., Cao, J., Mokhtarian, P.L. (2018) The association between spatial attributes and e-shopping in the shopping process for search goods and experience goods: Evidence from Nanjing. Journal of Transport Geography, 66, 291-299. DOI:10.1016/j.jtrangeo.2017.11.007. 